\title{
Gender and climate risk management: evidence of climate information use in Ghana
}

\author{
Samuel T. Partey ${ }^{1}$ (D) Angela D. Dakorah ${ }^{2}$. \\ Robert B. Zougmoré ${ }^{1} \cdot$ Mathieu Ouédraogo ${ }^{1}$. \\ Mary Nyasimi ${ }^{3}$ - Gordon K. Nikoi ${ }^{4}$-Sophia Huyer ${ }^{3}$
}

Received: 22 September 2017 / Accepted: 19 June 2018 / Published online: 5 July 2018

(C) The Author(s) 2018

\begin{abstract}
The gender perspective of climate information use is not well studied although necessary for developing gender-responsive climate information services (CIS). This study determined how CIS use by men and women farmers may be influenced by their perceptions about climate change (CC), farm activities, and demography. The study was carried out at the Lawra-Jirapa Districts of the Upper West Region of Ghana where downscaled seasonal forecast information through mobile phone technologies (Esoko platform) had been disseminated to farmers since 2011. Data was collected from semi-structured questionnaire interviews involving 900 farmers (50.2\% women and $49.8 \%$ men) and four 20-member focus group discussions. The study confirmed $85.2 \%$ (representing 767) farmers were aware of climate change and its implications for their agriculture and other livelihood activities. Men and women had similar perceptions about climate change, perceived by the majority as increased strong winds, higher temperatures, increased frequency of drought, increased rainfall variability and increased flooding. Among other factors, it was evident that use of CIS may be influenced by gender. Men were found to be particularly responsive in adopting CIS use for climate risk mitigation. This was attributed to their ability to easily access and use telephone devices compared with women. The study revealed that unlike women, men were able to
\end{abstract}

This article is part of a Special Issue on "Gender Responsive Climate Smart Agriculture: Framework, Approaches and Technologies” edited by Sophia Huyer and Samuel Tetteh Partey.

Samuel T. Partey

s.partey@cgiar.org

1 CCAFS, International Crops Research Institute for the Semi-Arid Tropics (ICRISAT), BP 320, Bamako, Mali

2 Faculty of Renewable Natural Resources, Kwame Nkrumah University of Science and Technology, University Post Office, PMB, Kumasi, Ghana

3 CCAFS, Centro Internacional de Agricultura Tropical, KM17, Recta Cali-Palmira, Apartado Ae'reo 6713, Cali, Colombia

4 Esoko Limited, 42 Ring Road Central, Accra, Ghana 
access more financial resources and had control of household income which allowed them to purchase mobile phones. Women generally accessed their husbands' mobile phones. Despite differences in access to CIS, the study showed both men and women found it beneficial for strategic farm decision-making such as when to begin land preparation, when to plant, and which crop to select. In addition, both men and women were found to face similar constrains (such as poor network connectivity and limited of training), to accessing and using CIS through the Esoko platform. The study recommends the need to explore different CIS dissemination channels and design CIS that meet gender-specific needs.

\section{Introduction}

Generally, women farmers in Sub-Saharan Africa are thought to be more vulnerable to climate change and greatly affected by its impacts (Beuchelt and Badstue 2013). In addition to their limited access to farm resources such as improved seeds, land, agricultural extension, and financial services, the roles and responsibilities of women within the household such as collecting fuelwood and water increase their sensitivity to climaterelated risks (Wright and Chandani 2014; Jost et al. 2016). With about 40-60\% women involved in agriculture in Africa, increasing their resilience to climate change is thought to be an important step in improving food security in the region (Doss 2018).

In West Africa, agriculture experts and development actors are pushing for the mainstreaming of climate-smart agriculture into agriculture development plans and policies to increase the adaptive capacity of resource-poor farmers to build resilient livelihoods (Partey et al. 2018; Zougmoré et al. 2016). Among many sound climate-smart approaches, the World Meteorological Organization (WMO) is of the view that giving farmers access to climate information for farm management decision-making will be crucial for mitigating climate-related risks (WMO 2013). With climate information, farmers can strategically plan their farm operations and adopt strategies that improve their adaptive capacity in the face of climate risks. Substantial benefits of climate information in agroecosystems have been reported for several countries in Africa. In Senegal, an estimated seven million rural populations are said to have access to climate information services (CIS) delivered through rural radios, supporting fishing communities, pastoralists, and crop producers in management of farm-related and other livelihood activities (Zougmoré and Ndiaye 2015). In Mali, Niger, and Burkina Faso, seasonal forecast information reportedly helped millet and sorghum farmers make mixed strategic decisions such as when to apply manure or chemical fertilizers and when to sow crops (Roudier et al. 2014). In addition, through the Participatory Integrated Climate Services for Agriculture (PICSA) approach, farmers in Tanzania, Malawi, Ghana, and Lesotho analyze historical climate information under the guidance of agricultural extension staff to develop and to choose crop, livestock, and livelihood options best suited to individual farmers' circumstances (Hansen et al. 2016). Ouédraogo et al. (2015) showed that farmers accessing CIS used fewer inputs (e.g. organic manure, fertilizers) in cowpea and sesame production systems compared with those who did not. However, notwithstanding the reported benefits of CIS, there remain major gaps in gender analysis of how differences in access to farm resources for men and women and their socially differentiated roles and responsibilities at the household level may influence their access and use of CIS (Kristjanson et al. 2014). 
In 2011, the CGIAR Research Program on Climate Change, Agriculture and Food Security (CCAFS) initiated a pilot project aimed at generating a Public-Private Partnership that would provide sustainable dissemination of CIS to farmers through Information and Communication Technology (ICT) platforms. This project is piloted at the CCAFS Climate-Smart Village (CSV) research for development (R4D) sites in Ghana (Lawra and Jirapa districts). Through collaboration between Esoko (an ICT company) and the Ghana Meteorological Agency, downscaled seasonal forecast information and agroadvisories have for the past 5 years been disseminated to farmers through mobile phones. Farmers accessed climate information on their phones as voice alerts, SMS, or by calling an Esoko-led call center. In addition, Esoko provides agro-advisories in collaboration with the Council for Scientific and Industrial Research, a national agricultural research institute, to help farmers apply the best climate-smart agriculture (CSA) technologies based on the seasonal forecast information received. To date, over 1000 farmers (including 33\% women) have subscribed to the Esoko platform. While there is growing evidence that climate information delivered through the Esoko platform could be beneficial to farmers (Etwire et al. 2017), information on the benefits to women of this useful decision-making tool is limited. Jost et al. (2016) reported that to effectively target women and improve their use of CSA technologies, socioeconomic studies on the use of agricultural innovations must include gender analysis for the development of policies that improve gender inequalities in the access and use of agricultural resources. This study is therefore novel and aimed to determine (1) whether perceptions on climate change and variability differ between men and women farmers; (2) whether gender is a determinant of climate information use; and (3) whether men and women benefit and face similar constraints to the use of climate information services. Findings of this study will be crucial for the development of gender-responsive CIS that helps women mitigate climate-related risks and build resilient livelihoods. Gender in this study refers only to sex type (male or female).

\section{Materials and methods}

\subsection{Study site}

The study was carried out at the CCAFS climate-smart village research for development site (CSV 4RD) in the Lawra and Jirapa Districts of the Upper West Region of Ghana, where downscaled seasonal forecast information through mobile phone technologies has been disseminated to farmers since 2011 (Fig. 1). Locations within the district used in the study include Tabier, Orbili, Tuori, Bompari, Dazuuri, Wulling, Die, Jeffiri, Baazu, and Doggoh. The sites lie within the Guinea Savannah Zone, which is characterized by a unimodal rainfall pattern induced by the moist monsoon winds, with an intensity of 1000-1100 mm per annum. Mean annual temperature is between 27 and $36{ }^{\circ} \mathrm{C}$ while humidity is about 70 to $90 \%$. Subsistence agriculture is the mainstay of the study location with common crops such as maize, cowpea, millet, sorghum, yam, and groundnut. Cash crops cultivated include cotton, shea nuts, groundnuts, and cashew. Farmers also keep cattle, sheep, goats, pigs, and poultry to supplement crop production (Ghana Statistical Service 2014). 


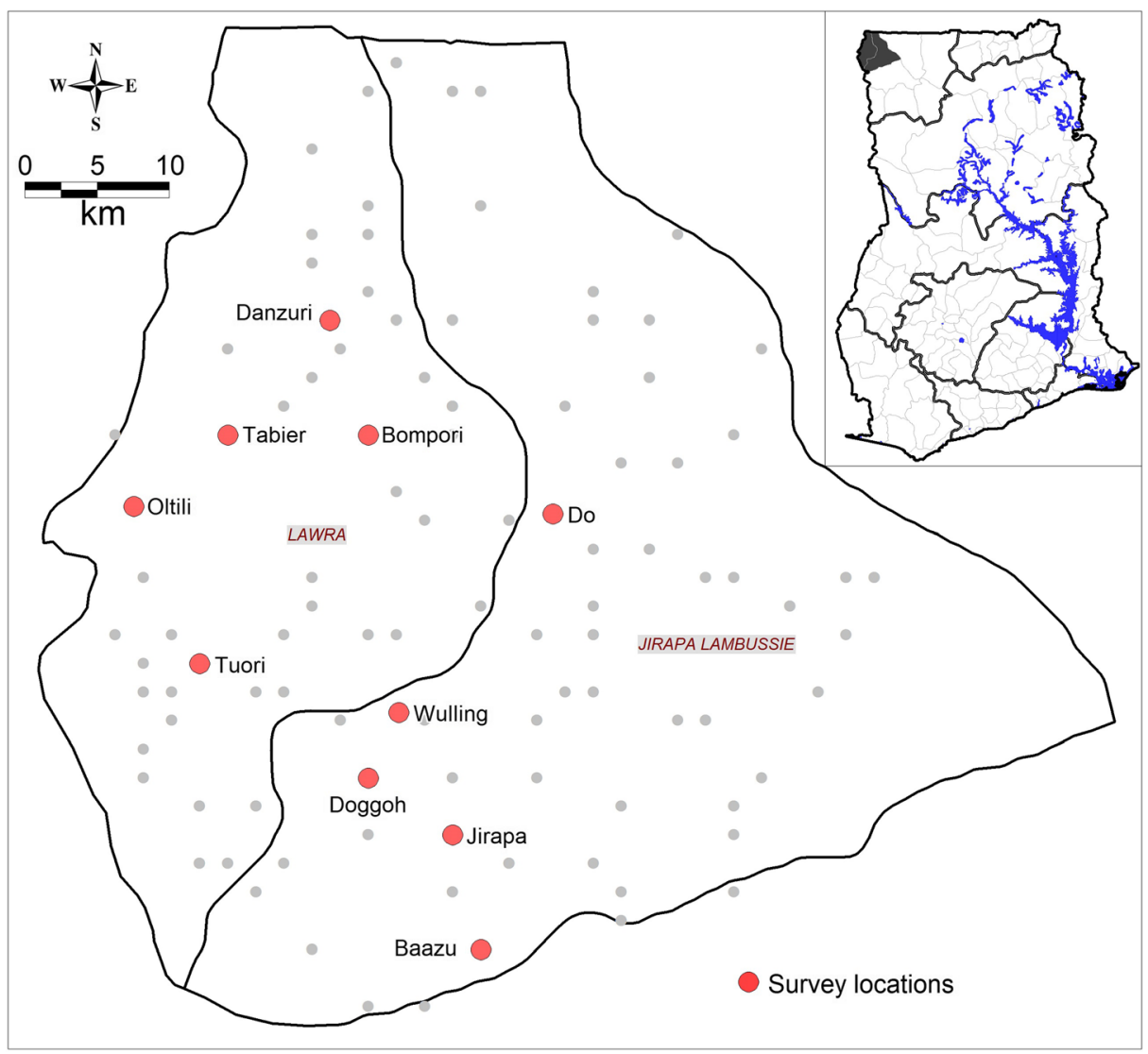

Fig. 1 A map showing study locations within the Lawra-Jirapa Districts of the Upper West Region of Ghana

\subsection{Data collection and analysis}

Data were collected through focus group discussions and semi-structured questionnaire interviews. A total of four focus groups were conducted in November 2016 in the study area. Each focus group involved a different set of participants who had access and use of climate information disseminated by Esoko. The 20 participants in each group were recruited from the farming population of the study area. Of these, three were homogenous (involving only men or women) and one heterogeneous (involving an equal number of men and women). These different compositions of focus groups were necessary to generate gender-specific information. Each group was conducted with three research team members: one played the role of a moderator, while two members recorded information and contributed follow-up questions to probe issues further. The focus groups were conducted in Dagaari which is the native language of the study area and were translated, transcribed, and analyzed in English. Issues discussed in the focus group included (1) climate change perception, (2) benefits and constraints to seasonal forecast application, and (3) willingness to pay for climate information services. There was no evidence of significant differences between the responses of the different focus groups. 
Semi-structured questionnaires were also administered to 900 farmers $(50.2 \%$ women and $49.8 \%$ men) to complement the qualitative information from the focus group discussions. The 900 farmers were randomly selected from a pool of farmers involved in the different CCAFS projects at the study location. Selected farmers were either subscribed to the Esoko platform or not. Open-ended questions were used to generate data on farmers' demography, farm production systems, climate change perception, and access and use of climate information for climate risk mitigation. Farmers with access to climate information were asked about the benefits and constraints to accessing and using climate information in relation to farm management decisions and other livelihood activities. In addition, we related farmers' perceptions on climate change and variability (mainly on temperature and rainfall) to historical rainfall and temperature data generated by the Ghana Meteorological Agency from 1983 to 2014.

A combination of descriptive and inference statistical approaches such as chi-square and logit models were used to analyze data collected where applicable. Chi-square tests were employed in cross-tabulations between variables whereas logit models were used to analyze the relationship between a binary dependent variable and a set of independent variables, whether binary or continuous. The logistic model for " $k$ " independent variables $\left(\mathrm{X}_{\mathrm{i}}, \mathrm{X}_{2}\right.$, $\mathrm{X}_{3}, \ldots, \mathrm{X}_{\mathrm{k}}$ ) is given by Eq. 1 :

$$
\text { Logit } \mathrm{P}(\mathrm{X})=\alpha+\sum_{i=1}^{k} \beta_{i} x_{i}
$$

$\operatorname{Exp}\left(\beta_{i}\right)$ indicates the odds ratio for a person having characteristics $i$ versus not having $i$, while $\beta_{i}$ is the regression coefficient, and $\alpha$ is a constant (Fosu-Mensah et al. 2012).

Data was analyzed using Stata 14.1.

\subsubsection{Hypotheses of how gender may influence climate change perception and uptake of climate information services}

The dependent variables in this study were climate change perception and use of climate information services while the explanatory variables included gender disaggregated data on demography of farmers (e.g. age, level of education, household income, access to radio, mobile phone, and TV), characteristics of farming systems (e.g. type of farming, objective of farming, farming experience, farm size), and access to farm inputs and credits (e.g. fertilizers, seeds, and land). These factors were considered in this study as earlier studies had shown they may influence climate change perception and necessitate the adoption of climate risk mitigation strategies including accessing and using climate information services (Deressa et al. 2009; Fosu-Mensah et al. 2012). Therefore, depending on how men and women are characterized by the aforementioned factors, one may likely be more knowledgeable about climate change and/or adopt technologies such as climate information services relevant for reducing vulnerability to climate-related risks and building adaptive capacity. For instance, Lin (1991) found that level of education and years of farming experience are positively correlated to climate change knowledge and willingness to try or adopt climate change adaptation strategies. Therefore, depending on how men and women differ with respect to their level of education and years of farming experience their understanding of climate change or variability and uptake of CIS may also differ. Again, considering the relatively high financial cost of adopting agricultural technologies (Knowler and Bradshaw 2007), farmers with higher incomes may be less vulnerable, have easier access to information, have a lower discount rate, have a longer term planning horizon, and be more open to new technologies such as climate 
information services (Nhemachena and Hassan 2007; Fosu-Mensah et al. 2012). For this reason, we hypothesized that male and female farmers are likely to differ on their access and use of climate information services due to their income levels. Lastly, there is growing consensuses that farmers with access to agricultural extension and media (e.g. television, radio) are more aware and knowledgeable about environmental issues and other factors that may affect their farming activities (Bryan et al. 2009; Deressa et al. 2009). In this regard, they are able to make more informed decisions that reduce cost of inputs and improve the overall productivity of their farms.

\section{Results and discussion}

\subsection{Gender distribution of respondents}

Farmers interviewed comprised 50.2\% women and 49.8\% men. Most of the respondents (61\%) were outside of the youth category (18-35) according to the definition in Ghana (Ghana statistical service 2014), with comparable male and female distribution (Table 1). Although the sampling procedure may have been biased towards the normal adults, this sample reflects the demographics in the region, since a decline in youth involvement in agriculture has been reported for the study location and its environs (Ghana statistical service 2014). This is also similar to general observations in many parts of Sub-Saharan Africa (Swarts and Aliber 2013) where low youth participation in agriculture has been recorded. Meanwhile, the majority of farmers interviewed in the study owned their own lands although most were males (68\% as against $32 \%$ women). This finding confirms reports on gender inequalities in land ownership in Africa (Doss et al. 2015; Njoh and Ananga 2016). In the focus groups, respondents confirmed most women farm on land of less than 1 ha, with land sizes for both men and women not exceeding 5 ha. Such land sizes are characteristic of Africa's subsistence farmers which adds to the growing evidence that agriculture production systems in Africa need to be intensified and diversified to meet the food security requirements of the region (Tittonell and Giller 2013; Palm et al. 2017).

The study also revealed about $72 \%$ of farmers were generally resource-poor with monthly incomes below the national minimum monthly wage of Ghana (264 Ghana Cedis) (National Tripartite Committee 2017). Within this bracket, women made up the largest proportion (Table 1). Income disparities between men and women are highly documented in the literature (e.g. Seguino and Were 2014; Pérez et al. 2015). Comparatively, women also had low access to farm inputs such as fertilizers, improved seeds, and irrigation, as revealed by the study. Low-income levels and multiple factors such as limited access to land and farm inputs are considered a threat to women's ability to adapt to climate change risks compared to men (Posel et al. 2016). While education levels were similar between men and women; the $70 \%$ illiteracy level recorded may have implications on behavioral changes towards acceptance and adoption of new technologies.

\subsection{Gender and climate change perception}

The results confirmed $85.2 \%(N=900)$ of farmers were aware of climate change and its implications for their agriculture and other livelihood activities. Evidence of awareness of climate change was based on experiential knowledge and ability to narrate evidence of 
Table 1 Characteristics of respondents based on gender

\begin{tabular}{|c|c|c|c|c|}
\hline Variable & Code & Female $=0(\%)$ & Male $=1(\%)$ & Total $(\%)$ \\
\hline \multicolumn{5}{|l|}{ Age (years) } \\
\hline Youth $(18 \text { to } 35)^{1}$ & 0 & 20.0 & 19.2 & 39.2 \\
\hline Older (36 and above) & 1 & 30.2 & 30.6 & 60.8 \\
\hline \multicolumn{5}{|l|}{ Education level } \\
\hline No formal education & 0 & 35.4 & 34.3 & 69.8 \\
\hline Formal education (primary to university) & 1 & 14.8 & 15.4 & 30.2 \\
\hline \multicolumn{5}{|l|}{ Farming type } \\
\hline Not engaged in crop production & 0 & 16.4 & 2.0 & 18.4 \\
\hline Engaged in crop production & 1 & 33.8 & 47.8 & 81.6 \\
\hline Not engaged in livestock production & 0 & 33.3 & 47.2 & 80.6 \\
\hline Engaged in livestock production & 1 & 16.9 & 2.6 & 19.4 \\
\hline \multicolumn{5}{|l|}{ Land ownership } \\
\hline Not owned & 0 & 33.8 & 14.4 & 48.2 \\
\hline Owned & 1 & 16.4 & 35.3 & 51.8 \\
\hline \multicolumn{5}{|l|}{ Monthly income (Ghana Cedis) } \\
\hline Below national monthly minimum wage ${ }^{2}$ & 0 & 37.4 & 34.2 & 71.7 \\
\hline National monthly minimum wage and above & 1 & 12.8 & 15.6 & 28.3 \\
\hline \multicolumn{5}{|l|}{ Farm experience (years) } \\
\hline Less than 10 years & 0 & 26.4 & 26.4 & 52.9 \\
\hline 10 years and above & 1 & 23.8 & 23.3 & 47.1 \\
\hline \multicolumn{5}{|l|}{ Media and extension services } \\
\hline No access to TV & 0 & 38.1 & 5.2 & 43.3 \\
\hline Access to TV & 1 & 12.1 & 44.6 & 56.7 \\
\hline No access to radio & 0 & 39.7 & 8.8 & 48.4 \\
\hline Access to radio & 1 & 10.6 & 41.0 & 51.6 \\
\hline No access to agric extension & 0 & 41.8 & 21.4 & 63.2 \\
\hline Access to agric extension & 1 & 8.4 & 28.3 & 36.8 \\
\hline No access to telephone & 0 & 30.4 & 14.4 & 44.9 \\
\hline Access to telephone & 1 & 19.8 & 35.3 & 55.1 \\
\hline \multicolumn{5}{|l|}{ Farm inputs } \\
\hline No access to fertilizer & 0 & 35.1 & 10.3 & 45.4 \\
\hline Access to fertilizer & 1 & 15.1 & 39.4 & 54.6 \\
\hline No access to irrigation & 0 & 39.8 & 36.1 & 75.9 \\
\hline Access to irrigation & 1 & 10.4 & 13.7 & 24.1 \\
\hline No access to improved seeds ${ }^{2}$ & 0 & 34.4 & 8.2 & 42.7 \\
\hline Access to improved seeds & 1 & 15.8 & 41.6 & 57.3 \\
\hline
\end{tabular}

$N=900$

${ }^{1}$ Youth age of Ghana is 18 to 35 years according to the Ghana Statistical Services (2014)

${ }^{2}$ Minimum monthly wage of Ghana as at the time of the study (November 2016) was 264 Ghana Cedis

${ }^{3}$ Improved seeds include all seeds developed to produce higher yields or withstand biotic and abiotic-related stresses

climate change or variability manifestations. The high awareness of climate change and variability was expected and consistent with research reports in most of West Africa where between 71 and $95 \%$ of farmers are reported to be aware of climate change (FosuMensah et al. 2012; Gbetibouo 2009), which they associated with significant changes in temperature and precipitation over decades. Meanwhile, the results also revealed gender was not a significant $(p=0.599)$ determinant of climate change and variability awareness (Table 2). As climate change and variability impacts both men and women, differences in awareness may not be highly expected, although men and women may experience 
Table 2 Logistic regression of farmer characteristics influencing awareness of climate change and variability

\begin{tabular}{lccrrrr}
\hline Variable & Coefficient & Std. Err. & $z$ & $P>z$ & $95 \%$ confidence intervals \\
\hline Age & 0.533 & 0.214 & 2.49 & 0.013 & 0.113 & 0.953 \\
Gender & -0.162 & 0.308 & -0.53 & 0.599 & -0.767 & 0.442 \\
Income & 0.140 & 0.228 & 0.62 & 0.538 & -0.306 & 0.586 \\
Being educated & 2.224 & 0.363 & 6.13 & 0.000 & 1.514 & 2.935 \\
Length of farming & 0.188 & 0.201 & 0.94 & 0.349 & -0.205 & 0.581 \\
Access to agric extension & -0.161 & 0.268 & -0.60 & 0.548 & -0.685 & 0.364 \\
Access to radio & -0.396 & 0.355 & -1.11 & 0.265 & -1.092 & 0.300 \\
Access to TV & 0.768 & 0.367 & 2.09 & 0.036 & 0.049 & 1.487 \\
Access to telephone & -0.104 & 0.213 & -0.49 & 0.625 & -0.523 & 0.314 \\
Access to improved seeds & -0.676 & 0.639 & -1.06 & 0.290 & -1.928 & 0.576 \\
Access to fertilizer & 0.535 & 0.559 & 0.96 & 0.339 & -0.561 & 1.632 \\
Engaged in crop production & -1.226 & 0.984 & -1.25 & 0.213 & -3.155 & 0.702 \\
Engaged in livestock production & -0.740 & 0.944 & -0.78 & 0.433 & -2.590 & 1.111 \\
Land ownership & 0.300 & 0.223 & 1.35 & 0.177 & -0.136 & 0.736 \\
Constant & 1.980316 & 1.00681 & 1.97 & 0.049 & 0.0070056 & 3.9536 \\
\hline
\end{tabular}

$N=900 ;$ Prob $>$ chi $^{2}=0.0000 ;$ Log likelihood $=-342.90801 ;$ pseudo $R^{2}=0.0945$. Significant variables are in italic

differences in the severity of impact due to differences in vulnerabilities. While access to $\mathrm{TV}$, age, and education were significant $(p<0.05)$ determinants of climate change awareness, access did not differ significantly between men and women. Meanwhile, the significant influence of access to $\mathrm{TV}$, age and education on climate change awareness as revealed in the present study are consistent with findings in the literature (e.g. Bryan et al. 2009; Deressa et al. 2009). The results however contradict the reports by some authors (e.g. Fosu-Mensah et al. 2012; Smit and Skinner 2002) that confirm access to agriculture extension may improve a farmer's knowledge of climate change. Generally, farmers perceived climate change manifestations as increased strong winds (confirmed by $55 \%$ of respondents); higher temperature (78\%), increased frequency of drought $(77 \%)$, increased rainfall variability during crop growing seasons $(71 \%)$, and increased flooding (78\%). Respondents associated their experiential knowledge of climate change to various occurrences observed over the past decades. These include the following: (1) drying up of surrounding rivers; (2) current unacceptable yields of major food crops (such as millet, sorghum, maize, cowpea, and groundnut) even with improved germplasm; (3) reduced vegetation cover which has deteriorated the microclimate for livestock; and (4) increased flooding which increases erosion and run-off on farm lands. From analysis of the meteorological data (on temperature and precipitation) in the study area, there was little evidence of change in temperature, but significant variabilities in rainfall (Fig. 2a, b) were recorded. Farmers' perception of rainfall variability is therefore consistent with the meteorological information.

\subsection{Gender and use of climate information services}

Out of the 900 respondents, 51\% (comprising 17\% women and 34\% men) used climate information. Respondents confirmed receiving downscaled seasonal forecast information through the Esoko platform. The Esoko platform was the only source of climate information services. Information received was used in farm management planning and 


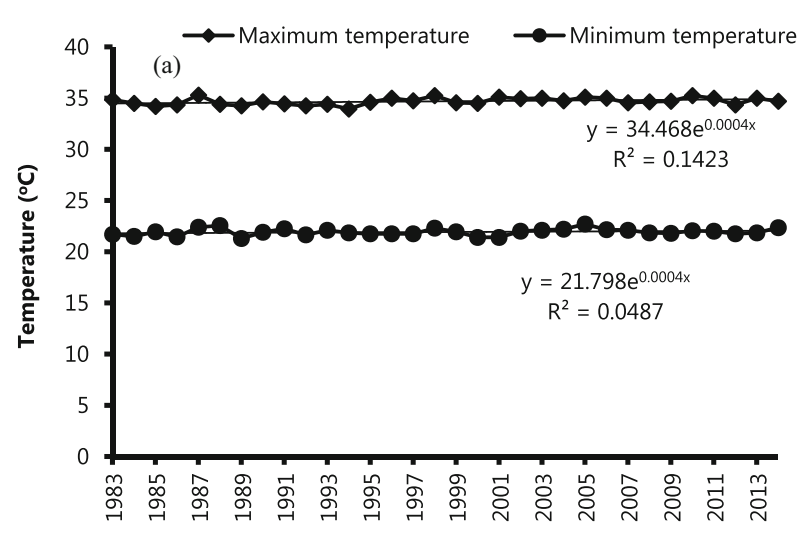

Time (years)

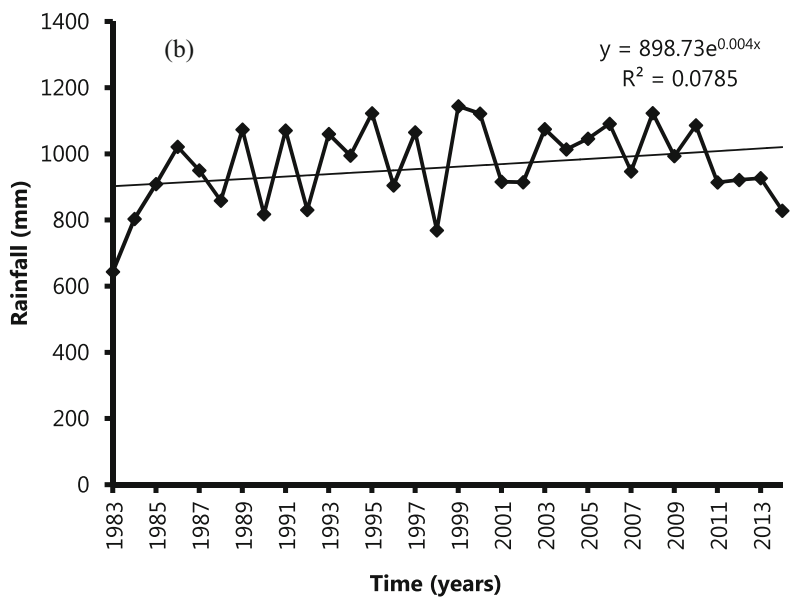

Fig. 2 Historical mean temperature (a) and mean annual rainfall (b) of the CCAFS CSV sites in the LawraJirapa district of the Upper West Region of Ghana

decision-making such as selection of crop variety for the season, time of planting, timing of land preparation, and when to apply fertilizer (Fig. 3). Among other factors, it was evident that the choice of using climate information services was significantly $(p<0.001)$ influenced by increased drought frequency and increased rainfall variability in the study area (Table 3). It is expected that with increasing unpredictability of rains and recurrent droughts, climate information services will be crucial for reducing crop failures, improving farm productivity, reducing cost of production, and ensuring resource use efficiency in agroecosystems. Therefore, as weather patterns continue to vary, the demand for climate information services may increase. In that case, governments and development experts will need to explore investment opportunities and policies to promote the development and scaling up of CIS.

Among the demographic variables tested, a logistic regression showed gender, access to telephone, access to irrigation, crop production, livestock production, and land 


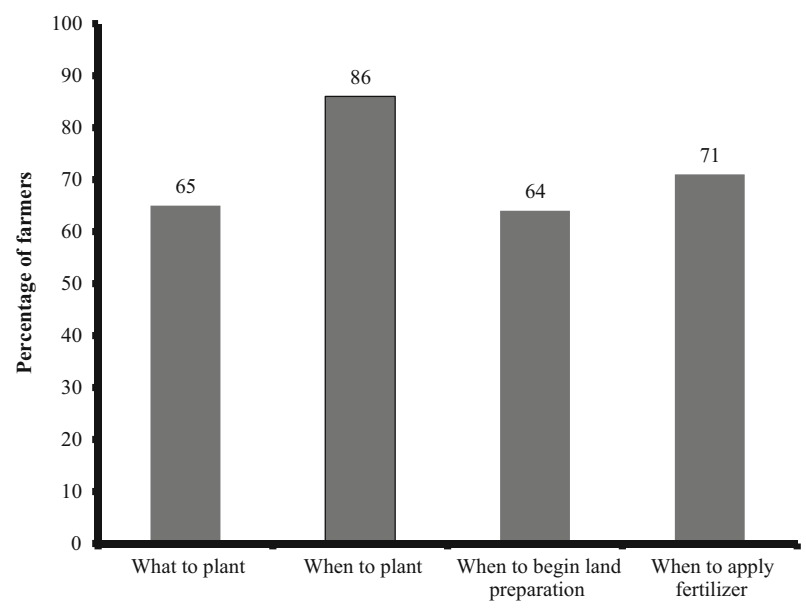

Fig. 3 Decisions made with climate information received from the Esoko platform at the CCAFS CSV sites in the Lawra-Jirapa district of the Upper West Region of Ghana. $N=462$

ownership were influential in determining whether or not someone will use climate information. From the analysis presented in Table 4, it is evident that in the context of the present study, men show a higher tendency to use climate information services than women. The effect of gender on the adoption of agricultural innovations is highly documented (Jost et al. 2016; McOmber et al. 2013). In the literature, differences in gender roles, preferences, vulnerabilities to climate-related risks, access to farm resources, land ownership, access to labor, access to information, and financial resources are often cited as significant determinants of adoption of agricultural innovations (Villamor et al. 2014; Bernier et al. 2015) since they influence behaviors and attitudes in changing farming practices. In Africa, both men and women have been cited as very responsive to technology adoption under different contexts where these factors favor either sex (Peterman et al. 2014). For instance, Gilbert et al. (2002) found high male adoption in maize cropping systems in Malawi which became gender-neutral after the supply of inorganic fertilizers to women. In Nigeria, Sanginga et al. (2007) found low adoption of improved seeds of soybean by women due to limited access to labor, while Jost et al. (2016) found that due to limited access to finance, extension services, and farm resources, women farmers in Uganda, Ghana, and Bangladesh (unlike men) did not significantly

Table 3 Logistic regression of perceived climatic events influencing the use of climate information

\begin{tabular}{lccrrrr}
\hline Variable & Coefficient & Std. err. & \multicolumn{1}{c}{$z$} & $P>z$ & 95\% confidence interval \\
\hline Increased strong winds & -0.091 & 4.659 & -0.02 & 0.984 & -9.223 & 9.040 \\
Increased temperature & 0.946 & 4.537 & 0.21 & 0.835 & -7.946 & 9.837 \\
Increased rainfall variability & 5.258 & 0.692 & 7.60 & 0.000 & 3.902 & 6.614 \\
Increased drought frequency & 8.440 & 0.703 & 12.00 & 0.000 & 7.062 & 9.819 \\
Increased floods & -0.268 & 1.218 & -0.22 & 0.826 & -2.655 & 2.119 \\
Constant & -5.343 & 0.690 & -7.74 & 0.000 & -6.696 & -3.991 \\
\hline
\end{tabular}

$N=900 ;$ Prob $>$ chi $^{2}=0.0000 ;$ Log likelihood $=-69.269785 ;$ pseudo $R^{2}=0.8889$. Significant variables are in italic 
Table 4 Logistic regression of farmer characteristics influencing the use of climate information services

\begin{tabular}{lcccccc}
\hline Variable & Coefficient & Std. err. & $z$ & $P>z$ & $95 \%$ confidence interval \\
\hline Age & -0.050 & 0.377 & -0.13 & 0.895 & -0.789 & 0.689 \\
Gender & 2.282 & 0.571 & 3.99 & 0.000 & 1.162 & 3.402 \\
Income & 0.333 & 0.467 & 0.71 & 0.476 & -0.583 & 1.249 \\
Being educated & 0.001 & 0.359 & 0 & 0.998 & -0.703 & 0.705 \\
Length of farming & 0.335 & 0.341 & 0.98 & 0.325 & -0.332 & 1.002 \\
Access to agric extension & 0.313 & 0.537 & 0.58 & 0.560 & -0.740 & 1.366 \\
Access to radio & 0.063 & 0.577 & 0.11 & 0.913 & -1.068 & 1.194 \\
Access to TV & -0.731 & 0.494 & -1.48 & 0.139 & -1.700 & 0.238 \\
Access to telephone & 7.722 & 0.630 & 12.25 & 0.000 & 6.486 & 8.958 \\
Access to improved seeds & 0.461 & 1.005 & 0.46 & 0.647 & -1.509 & 2.430 \\
Access to fertilizer & -0.638 & 0.798 & -0.8 & 0.424 & -2.203 & 0.926 \\
Access to irrigation & -1.148 & 0.511 & -2.25 & 0.025 & -2.150 & -0.147 \\
Engaged in crop production & 3.176 & 1.310 & 2.42 & 0.015 & 0.607 & 5.744 \\
Engaged in livestock production & 5.987 & 1.349 & 4.44 & 0.000 & 3.342 & 8.632 \\
Land ownership & 1.045 & 0.395 & 2.65 & 0.008 & 0.272 & 1.819 \\
Constant & -9.929 & 1.606 & -6.18 & 0.000 & -13.076 & -6.781 \\
\hline
\end{tabular}

$N=900 ;$ Prob $>\mathrm{chi}^{2}=0.0000 ;$ Log likelihood $=-140.6329 ;$ pseudo $R^{2}=0.7745$. Significant variables are in italic

adopt the use of climate information services and climate-smart agricultural practices to avert the risks of climate change and variability. Meanwhile, in Zambia, women farmers due to their role in collecting firewood were found to be most likely to adopt tree fallows (Phiri et al. 2004) while women in Uganda were found to be more likely to use organic manure to improve soil fertility because of their limited access to fertilizers (Goldman and Heldenbrand 2001).

In the context of this study, the higher probability that men will use climate information may be related to their ability to easily access telephone devices which are the main equipment for receiving climate information from the Esoko ICT platform. In this study, a more significant number of men $(35.3 \%)$ than women $(20 \%)$ had access to mobile phones. In the focus group discussions, women acknowledged the importance of mobile phones to access CIS but cited their low-income levels as the major constraint to the acquisition of the device. Studies on the gender perspectives of mobile phone access and use in Africa generally reveal inequalities among men and women (e.g. Gillwald et al. 2010) which are consistent with the findings of this study. Some authors have argued that although mobile phone use is on the increase in Africa, women are $21 \%$ less likely than men to own mobile phones (McOmber et al. 2013; Gillwald et al. 2010). For example in 17 African countries, Gillwald et al. (2010) found that more men than women in 13 of the countries own mobile phones. This has been attributed to low incomes of women and their inability to control household incomes. In some cases, such as in the community where this study was carried out, women more often than not expect their husbands to buy them equipment such as farm tools, TV, radio, and mobile phones due to the husband's control of household income. As a result, the acquisition of mobile phones by women will among other factors be dependent on the willingness of their husband, his financial capacity, and whether he perceives it to be necessary for his wife to own or have access to one. This situation relates to a growing advocacy for gender empowerment in developing countries so that the low financial status of women does not constrain them 
from making decisions that benefit them personally. Gender-specific needs for climate change adaptation, must be mainstreamed into the design of climate information services to improve their equity and effectiveness for both men and women farmers. While development experts may foster gender-sensitive activities that empower women financially, various dissemination channels of CIS must also be explored to ensure women have easy access to this important decision support service (Tall et al. 2014). By promoting policies and development programs that improve women's access and use of CIS, they can boost their agricultural and other livelihood activities for immense contribution towards household food and financial security. Such policies and programs may include providing incentives for the education of women in ICT and building their capacities to indulge in other income generating activities (such agro-processing) that can empower them financially to acquire agricultural inputs and mobile phones (DeenSwarray et al. 2012).

\subsection{Constraints to climate information use}

Although climate information was found to be highly beneficial to farmers, farmers subscribing to the Esoko platform listed some constraints that may limit the effectiveness and long-term use of the platform for receiving seasonal forecast information. While men and women farmers referred to similar benefits from use of climate information, the focus group discussions showed men and women had varying pressing challenges with regard to accessing and using climate information through mobile phones. Table 5 shows the top five constraints experienced by male and female farmers in their quest to access and use climate information via mobile phones. Most of the constraints are related to lack of training, inability to interpret climate information and convert it into actions, limited access to mobile phones (mostly by women), and inability to afford calling credits. Development experts, the government and private sector have a stake in building capacities, providing logistical support and providing the enabling environment for the generation and dissemination of accurate and reliable climate information that benefits both men and women equally.

Table 5 Constraints to effective use of climate information delivered through mobile phones in the CCAFS CSV sites in the Lawra-Jirapa district of the Upper West Region of Ghana

\begin{tabular}{ll}
\hline Male & Female \\
\hline $\begin{array}{l}\text { Limited training on interpreting weather information } \\
\text { received }\end{array}$ & $\begin{array}{r}\text { Little or no formal education hindering our ability to read } \\
\text { and understand the text messages sent by the Esoko } \\
\text { platform }\end{array}$ \\
$\begin{array}{l}\text { The forecast information is sometimes different from } \\
\text { the actual weather condition }\end{array}$ & $\begin{array}{l}\text { Periodically, educated community members unable to } \\
\text { correctly interpret text messages } \\
\text { Bad network connection }\end{array}$ \\
$\begin{array}{l}\text { Long waiting times on calls placed to the call center } \\
\text { Lack of access to mobile phones as the service is phone } \\
\text { Periodically, the translators at the Esoko call center } \\
\text { are not available and they do not call back either }\end{array}$ & $\begin{array}{r}\text { Lack of means of transportation on reported market days } \\
\text { in various communities prevents farmers from moving } \\
\text { to sell farm produce }\end{array}$ \\
\hline
\end{tabular}




\section{Conclusions}

The study confirmed increased awareness of climate change with no significant differences in climate change perception between men and women. Among other factors, it was evident that use of climate information may be influenced by gender. Men were found to be particularly responsive in adopting climate information use for climate risk mitigation. This was attributed to their easier access to telephone devices compared with women. The study revealed that unlike women, men had more financial capacity and had control of household income to purchase mobile phones. Regardless of gender, the study showed that increased rainfall variability and increased drought frequency in the study area had significant influence on farmers' use of climate information services (CIS). This confirmed climate change perception may influence uptake of CIS. With the evidence that limited access to mobile phone and call credits (mostly by women), and bad network connections among other barriers may constrain future uptake of CIS, a viable public-private partnership or scheme that builds capacity of farmers and provides them with the logistical support to effectively apply climate information will be crucial for building their adaptive capacity to climate change and variability. In addition, the design of climate information services must consider gender-specific needs including exploring various dissemination channels that address the constraints experienced by women, to ensure the development of a gender-responsive decision support service. By improving women's access and use of CIS, they can play important roles in household climate change adaptation planning.

Acknowledgements This work was implemented as part of the CGIAR Research Program on Climate Change, Agriculture and Food Security (CCAFS), a strategic partnership of CGIAR and Future Earth, led by the International Center for Tropical Agriculture (CIAT). We acknowledge the CGIAR Fund Council, Australia (ACIAR), European Union, International Fund for Agricultural Development (IFAD), Ireland, New Zealand, Netherlands, Switzerland, USAID, UK, and Thailand for funding the CCAFS.

Open Access This article is distributed under the terms of the Creative Commons Attribution 4.0 International License (http://creativecommons.org/licenses/by/4.0/), which permits unrestricted use, distribution, and reproduction in any medium, provided you give appropriate credit to the original author(s) and the source, provide a link to the Creative Commons license, and indicate if changes were made.

\section{References}

Bernier Q, Meinzen-Dick R, Kristjanson P, Haglund E, Kovarik C, Bryan E, Ringler C, Silvestri S (2015) Gender and institutional aspects of climate-smart agricultural practices: evidence from Kenya. CCAFS Working Paper No. 79. CGIAR Research Program on Climate Change, Agriculture and Food Security (CCAFS). Copenhagen, Denmark. Available online at: www.ccafs.cgiar.org

Beuchelt TD, Badstue L (2013) Gender, nutrition-and climate-smart food production: opportunities and tradeoffs. Food Secur 5:709-721

Bryan E, Deressa TT, Gbetibouo GA, Ringler C (2009) Adaptation to climate change in Ethiopia and South Africa: options and constraints. Environ Sci Pol 12:413-426

Deen-Swarray M, Gillwald A, Morrell A (2012) Lifting the veil on ICT gender indicators in Africa. Research ICT Africa and University of Cape Town. Available at https://pdfs.semanticscholar.org/3a2b/1b7c48f46b6 a108f146fc1024451912978a2.pdf. Accessed 21st May 2018

Deressa TT, Hassan RM, Ringler C, Alemu T, Yesuf M (2009) Determinants of farmers' choice of adaptation methods to climate change in the Nile Basin of Ethiopia. Glob Environ Chang 19:248-255 
Doss CR (2018) Women and agricultural productivity: reframing the issues. Dev Policy Rev 36(1):35-50. https://doi.org/10.1111/dpr.12243

Doss C, Kovarik C, Peterman A, Quisumbing A, Bold M (2015) Gender inequalities in ownership and control of land in Africa: myth and reality. Agric Econ 46:403-434

Etwire PM, Buah S, Ouédraogo M, Zougmoré R, Partey ST, Martey E, Dayamba SD, Bayala J (2017) An assessment of mobile phone-based dissemination of weather and market information in the upper west region of Ghana. Agric Food Secur 6(1):8

Fosu-Mensah BY, Vlek PL, MacCarthy DS (2012) Farmers' perception and adaptation to climate change: a case study of Sekyedumase district in Ghana. Environ Dev Sustain 14:495-505

Gbetibouo AG (2009) Understanding farmers' perceptions and adaptations to climate change and variability. The case of the Limpopo Basin, South Africa. IFPRI Discussion Paper 00849

Ghana Statistical Service (2014) Population census-2010, district analytical report. Ghana Statistical Serice, Accra, Ghana

Gilbert RA, Sakala WD, Benson TD (2002) Gender analysis of a nationwide cropping system trial survey in Malawi. Available at http://agris.fao.org/agris-search/search.do?recordID=GB2013201770. Accessed 14 Feb 2018

Gillwald A, Milek A, Stork C (2010) Towards evidence-based ICT policy and regulation: gender assessment of ICT access and usage in Africa. Volume One. 2010 Policy Paper 5. Cape Town: Research ICT Africa Retrieved from www.ictworks.org/sites/default/files/uploaded_pics/2009/Gender_Paper_Sept_2010.pdf

Goldman A, Heldenbrand K (2001) Gender and soil fertility management in M̄̄ale District, southeastern Uganda. Afr Stud Q 6:45-76

Hansen J, Baron DM, Dinesh D, Ericksen P, Rodriguez AL, Aggarwal P (2016) Climate information services In: Dinesh D (ed) Agricultural practices and technologies to enhance food security, resilience and productivity in a sustainable manner: messages for SBSTA 44 agriculture workshops. CCAFS Working Paper no. 146. Copenhagen, Denmark: CGIAR Research Program on Climate Change, Agriculture and Food Security (CCAFS). Available online at: www.ccafs.cgiar.org

Jost C, Kyazze F, Naab J, Neelormi S, Kinyangi J, Zougmore R, Aggarwal P, Bhatta G, Chaudhury M, TapioBistrom ML, Nelson S (2016) Understanding gender dimensions of agriculture and climate change in smallholder farming communities. Clim Dev 8:133-144

Knowler D, Bradshaw B (2007) Farmers' adoption of conservation agriculture: a review and synthesis of recent research. Food Policy 32:25-48

Kristjanson P, Waters-Bayer A, Johnson N, Tipilda A, Njuki J, Baltenweck GD, MacMillan D (2014) Livestock and women's livelihoods: a review of the recent evidence. In: Quisumbing A, Meinzen-Dick R, Raney T, Croppenstedt A, Behrman JA, Peterman A (eds) Gender in agriculture Closing the knowledge gap. Springer with FAO, New York, pp 209-233

Lin J (1991) Education and innovation adoption in agriculture: evidence from hybrid rice in China. Am J Agric Econ 73:713-723

McOmber C, Panikowski A, McKune S, Bartels W, Russo S (2013) Investigating climate information services through a gendered lens. CCAFS Working Paper no. 42. CGIAR Research Program on Climate Change, Agriculture and Food Security (CCAFS). Copenhagen, Denmark. Available online at: www.ccafs.cgiar.org

National Tripartite Committee (2017) Minimum wage Ghana. Available at http://www.myjoyonline. com/news/2017/july-11th/daily-minimum-wage-goes-up-by-10.php. Accessed 21st September 2017

Nhemachena C, Hassan R (2007) Micro-level analysis of farmers' adaptation to climate change in southern Africa. IFPRI Discussion Paper No. 00714. International Food Policy Research Institute, Washington, D.C.

Njoh AJ, Ananga E (2016) The development hypothesis of women empowerment in the millennium development goals tested in the context women's access to land in Africa. Soc Indic Res 128:89-104

Ouédraogo M, Zougmoré R, Barry S, Somé L, Baki G (2015) The value and benefits of using seasonal climate forecasts in agriculture: evidence from cowpea and sesame sectors in climate-smart villages of Burkina Faso. CCAFS Info Note. CGIAR Research Program on Climate Change, Agriculture and Food Security (CCAFS), Copenhagen

Palm C, Neill C, Lefebvre P, Tully K (2017) Targeting sustainable intensification of maize-based agriculture in East Africa. Trop Conserv Sci 10:1-4

Partey ST, Zougmoré RB, Ouédraogo M, Campbell BM (2018) Developing climate-smart agriculture to face climate variability in West Africa: challenges and lessons learnt. J Clean Prod 187:285-295

Pérez C, Jones EM, Kristjanson P, Cramer L, Thornton PK, Förch W, Barahona CA (2015) How resilient are farming households and communities to a changing climate in Africa? A gender-based perspective. Glob Environ Chang 34:95-107

Peterman A, Behrman JA, Quisumbing AR (2014) A review of empirical evidence on gender differences in nonland agricultural inputs, technology, and services in developing countries. In: Gender in agriculture. Springer, Dordrecht, pp 145-186 
Phiri D, Franzel S, Mafongoya P, Jere I, Katanga R, Phiri S (2004) Who is using the new technology? The association of wealth status and gender with the planting of improved tree fallows in Eastern Province, Zambia. Agric Syst 79:131-144

Posel D, Casale D, Grapsa E (2016) Re-estimating gender differences in income in South Africa: the implications of equivalence scales. Dev South Afr 33:425-441

Roudier P, Muller B, d'Aquino P, Roncoli C, Soumaré MA, Batté L, Sultan B (2014) The role of climate forecasts in smallholder agriculture: lessons from participatory research in two communities in Senegal. Clim Risk Manag 2:42-55

Sanginga PC, Adesina AA, Manyong VM, Otite O, Dashiell KE (2007) Social impact of soybean in Nigeria's southern Guinea savanna Ibadan, Nigeria. International Institute of Tropical Agriculture, Ibadan

Seguino S, Were M (2014) Gender, development and economic growth in Sub-Saharan Africa. J Afr Econ 23: i18-i61

Smit B, Skinner MW (2002) Adaptation options in agriculture to climate change: a typology. Mitig Adapt Strateg Glob Chang 7:85-114

Swarts MB, Aliber M (2013) The 'youth and agriculture'problem: implications for rangeland development. Af J Range Forage Sci 30:23-27

Tall A, Kristjanson P, Chaudhury M, McKune S, Zougmore R (2014) Who gets the Information? Gender, power and equity considerations in the design of climate services for farmers. CCAFS Working Paper No. 89. CGIAR Research Program on Climate Change, Agriculture and Food Security (CCAFS). Copenhagen, Denmark. Available online at: www.ccafs.cgiar.org

Tittonell P, Giller KE (2013) When yield gaps are poverty traps: the paradigm of ecological intensification in African smallholder agriculture. Field Crop Res 143:76-90

Villamor GB, van Noordwijk M, Djanibekov U, Chiong-Javier ME, Catacutan D (2014) Gender differences in land-use decisions: shaping multifunctional landscapes? Curr Opin Environ Sustain 6:128-133

WMO (2013) Intergovernmental board on climate services. WMO Special Bulletin, p 62

Wright H, Chandani A (2014) Gender in scaling up community based adaptation to climate change. In: Schipper L, Ayers J, Reid H, Huq S, Rahman A (eds) Community based adaptation to climate change: scaling it up. Routledge, New York, pp 226-238

Zougmoré R, Ndiaye O (2015) Scaling up climate smart information services to guiding climate risk management by farmers in Senegal. In: Westermann, O., Thornton, P. and Förch, W., Reaching more farmersinnovative approaches to scaling up climate smart agriculture. CCAFS Working Paper no. 135. Copenhagen, Denmark: CGIAR Research Program on Climate Change, Agriculture and Food Security (CCAFS). Available online at: www.ccafs.cgiar.org

Zougmoré R, Partey S, Ouédraogo M, Omitoyin B, Thomas T, Ayantunde A, Ericksen P, Said M, Jalloh A (2016) Toward climate-smart agriculture in West Africa: a review of climate change impacts, adaptation strategies and policy developments for the livestock, fishery and crop production sectors. Agric Food Secur 5:26. https://doi.org/10.1186/s40066-016-0075-3 